Article

\title{
Preparation and Characterization of Zinc Oxide Nanoparticles Using Leaf Extract of Sambucus ebulus
}

\author{
Sanaz Alamdari $1, *\left(\mathbb{D}\right.$, Morteza Sasani Ghamsari ${ }^{2}{ }^{-}$, Chan Lee $^{3}$, Wooje Han ${ }^{3}$, \\ Hyung-Ho Park ${ }^{3, * \mathbb{D}}$, Majid Jafar Tafreshi ${ }^{4}$, Hosein Afarideh ${ }^{5}$ and \\ Mohammad Hosein Majles Ara ${ }^{6}$ \\ 1 Faculty of Physics, Semnan University, P.O. Box 35195-363, Semnan, Iran \\ 2 Photonics \& Quantum Technologies Research School, Nuclear Science, and Technology Research Institute, \\ Tehran 11155-3486, Iran; msghamsari@yahoo.com \\ 3 Department of Materials Science and Engineering, Yonsei University, 50 Yonsei-ro, Seodaemun-gu, \\ Seoul 03722, Korea; chanlee@yonsei.ac.kr (C.L.); wooje_han@yonsei.ac.kr (W.H.) \\ 4 Department of Physics, Semnan University, P.O. Box 35195-363, Semnan, Iran; m.tafreshi@semnan.ac.ir \\ 5 Department of Energy Engineering and Physics, Amirkabir University of Technology, Tehran 15875-4413, \\ Iran; hafarideh@aut.ac.ir \\ 6 Applied Science Research Center(ASRC), Kharazmi University, Tehran 31979-37551, Iran; \\ majlesara@gmail.com \\ * Correspondence: s.alamdari@semnan.ac.ir or alamdarisanaz@gmail.com (S.A.); \\ hhpark@yonsei.ac.kr (H.-H.P); Tel.: +98-31533221 (S.A.); +82-21232853 (H.-H.P); \\ Fax: +98-23-33654081 (S.A.); +82-2-3125375 (H.-H.P.)
}

Received: 26 March 2020; Accepted: 19 May 2020; Published: 23 May 2020

check for updates

\begin{abstract}
Plants are one of the best sources to obtain a variety of natural surfactants in the field of green synthesizing material. Sambucus ebulus, which has unique natural properties, has been considered a promising material in traditional Asian medicine. In this context, zinc oxide nanoparticles (ZnO NPs) were prepared using S. ebulus leaf extract, and their physicochemical properties were investigated. X-ray diffraction (XRD) results revealed that the prepared ZnO NPs are highly crystalline, having a wurtzite crystal structure. The average crystallite size of prepared NPs was around $17 \mathrm{~nm}$. Green synthesized NPs showed excellent absorption in the UV region as well as strong yellow-orange emission at room temperature. Prepared nanoparticles exhibited good antibacterial activity against various organisms and a passable photocatalytic degradation of methylene blue dye pollutants. The obtained results demonstrated that the biosynthesized ZnO NPs reveal interesting characteristics for various potential applications in the future.
\end{abstract}

Keywords: ZnO nanoparticles; Sambucus ebulus; extract; photocatalytic; antibacterial activity

\section{Introduction}

Zinc oxide $(\mathrm{ZnO})$ is a well-engineered compound that has received remarkable interest globally due to its distinctive properties and usages in various applications, such as pharmaceuticals, cosmetics, photonics, and photocatalysis [1-6].

$\mathrm{ZnO}$ nanoparticles (NPs) can be synthesized through many physiochemical routes, such as sol-gel processes, co-precipitation, laser vaporization, microemulsion, and ball milling [7-10]

Commonly, these preparation methods face several limitations, such as the high cost of equipment, the large area required for equipment set up, and additional use of capping agents, stabilizers and toxic chemicals [11]. Most of these chemical methods are not environmentally friendly due to the use of harsh chemicals for stabilizing processes, which will bind to the ZnO NPs, and limit their biological applications $[1,11]$. To overcome these limitations, green chemistry procedures have attracted 
significant scientific attention and have provided a new path for material researchers, because they are safe and environmentally friendly methods, which do not produce toxic by-products. Developing simple and green methods for synthesizing ZnO NPs is thus important, and remains a challenge for researchers [11,12].

According to the literature, plants extracts have been proposed as novel alternatives to chemical methods for synthesis of NPs [12-17]; for example, Iran and most parts of Asia have a rich source of valuable plants for this purpose [12,13]. It should be noted that most nanoparticles and plant extracts pose a threat to the ecosystem and human beings. Unregulated use in terms of their toxicity may affect the biological system in unanticipated ways. Better control of the synthetic parameters will undoubtedly help to improve not only the physiochemical properties of ZnO NPs but also their compatibility [14,18].

Extracts of citrus fruits or peels have been successfully used in producing metal and various metal oxide NPs, such as gold $(\mathrm{Au}) \mathrm{NPs}$, silver $(\mathrm{Ag}) \mathrm{NPs}$, and titanium dioxide $\left(\mathrm{TiO}_{2}\right) \mathrm{NPs}$ [19-21]. In addition, several types of fruit and plant extracts have been used for the synthesis of ZnO NPs, such as Limonia acidissima, Tabernaemontana divaricata, Cochlospermum religiosum, Conyza canadensis, Citrus maxima, Boswellia ovalifoliolata, Echinacea spp., Salvadora oleoides, and Aristolochia indica [22-33]. Zare et al. [33] reported the influence of Cuminum cyminum leaf extract on ZnO NP synthesis, which showed a good crystallite structure and high sensitivity to Gram-negative bacteria. In a similar study, Hibiscus sabdariffa and Acalypha indica extracts presented suitable optical and antibacterial properties [34]. Furthermore, $\mathrm{ZnO}$ NPs have shown promising properties in photocatalytic applications; it has been reported that Parkia roxburghii extract/ZnO NPs showed excellent degradation of methylene blue (MB) and Rhodamine B dyes, reaching about $98 \%$ [34].

Sambucus ebulus (elderberry or danewort), which is a natural plant with novel nutritional properties, grows in most parts of South America, Asia, North Africa, and the United States [35]. This plant is rich in biomolecules for reducing metal ions and stabilizing nanoparticles; S. ebulus leaf extract contains enormous numbers of carbonyl, carboxyl, and hydroxyl groups in polyphenols and flavonoids [35]. These compounds can have a positive effect on human health because they can act as antioxidants and anti-inflammatory and anticancer agents. Due to its easy collection, natural origin, and remarkable biological properties, it could be an ideal replacement for expensive modern chemical surfactants. As mentioned, S. ebulus contains high amounts of natural antioxidants, such as flavonoids, lectins, anthocyanins, vitamin $\mathrm{C}$, and phenolic compounds which may be considered as suitable stabilizing agents [35]. In our previous works, various $\mathrm{ZnO}$ nanostructures with novel properties were prepared using a chemical method; in our previous methods, we used triethanolamine (TEA) as a chemical surfactant for synthesis [36-44]. It is well-known that TEA, which is similar to many kinds of chemical surfactants, has a toxic hazard rating. In this study, we tried to use a plant extract as a natural surfactant instead of TEA. Notably, no previous study has been reported in the literature on the preparation of $\mathrm{ZnO}$ NPs using S. ebulus extract. The aim of this article is to report a novel room-temperature green synthesis of ZnO NPs using S. ebulus extract as a potential candidate for various applications with interesting structural, optical, photocatalytic, and antibacterial properties.

\section{Materials and Methods}

\subsection{Materials Preparation}

Young leaves of S. ebulus were picked in May 2018 in Sari, Mazandaran, Iran. All the chemical materials used in the experiments were purchased from Merck: zinc acetate dihydrate (99.7\%) and ethanol (99.5\%) as a solvent. The standard strains used for the tests were obtained from Alborz hospital at Karaj city and the University of Tarbiat Modares, Iran. Around $60 \mathrm{~g}$ of dried crushed leaves were added to $50 \mathrm{~mL}$ ethanol and left for $24 \mathrm{~h}$, after which the mixture was heated and stirred at $45^{\circ} \mathrm{C}$ for $2 \mathrm{~h}$, and the plant extract was then filtered with Whatman No. 1 filter paper twice. The filtrate was collected and kept at $4{ }^{\circ} \mathrm{C}$. This prepared extract was directly used in the synthesis experiments. $1 \mathrm{M}$ 
zinc acetate dihydrate was dissolved in $20 \mathrm{~mL}$ absolute ethanol and kept under continuous stirring for $30 \mathrm{~min}$ [37-44]. Approximately $2 \mathrm{~mL}$ of extract (as a natural surfactant) was added to the solution, followed by stirring for $2 \mathrm{~h}$ at $80^{\circ} \mathrm{C}$; the suspension was centrifuged at $7168 \mathrm{~g}$ for $15 \mathrm{~min}$, and the precipitate was dried at $60^{\circ} \mathrm{C}$ in a hot air oven until dried NPs were obtained. The prepared NPs were calcined at $450{ }^{\circ} \mathrm{C}$ for $2 \mathrm{~h}$. A schematic representation of the experimental work and possible chemical bond formed between the extracted molecules and zinc oxide are shown in Figure 1.

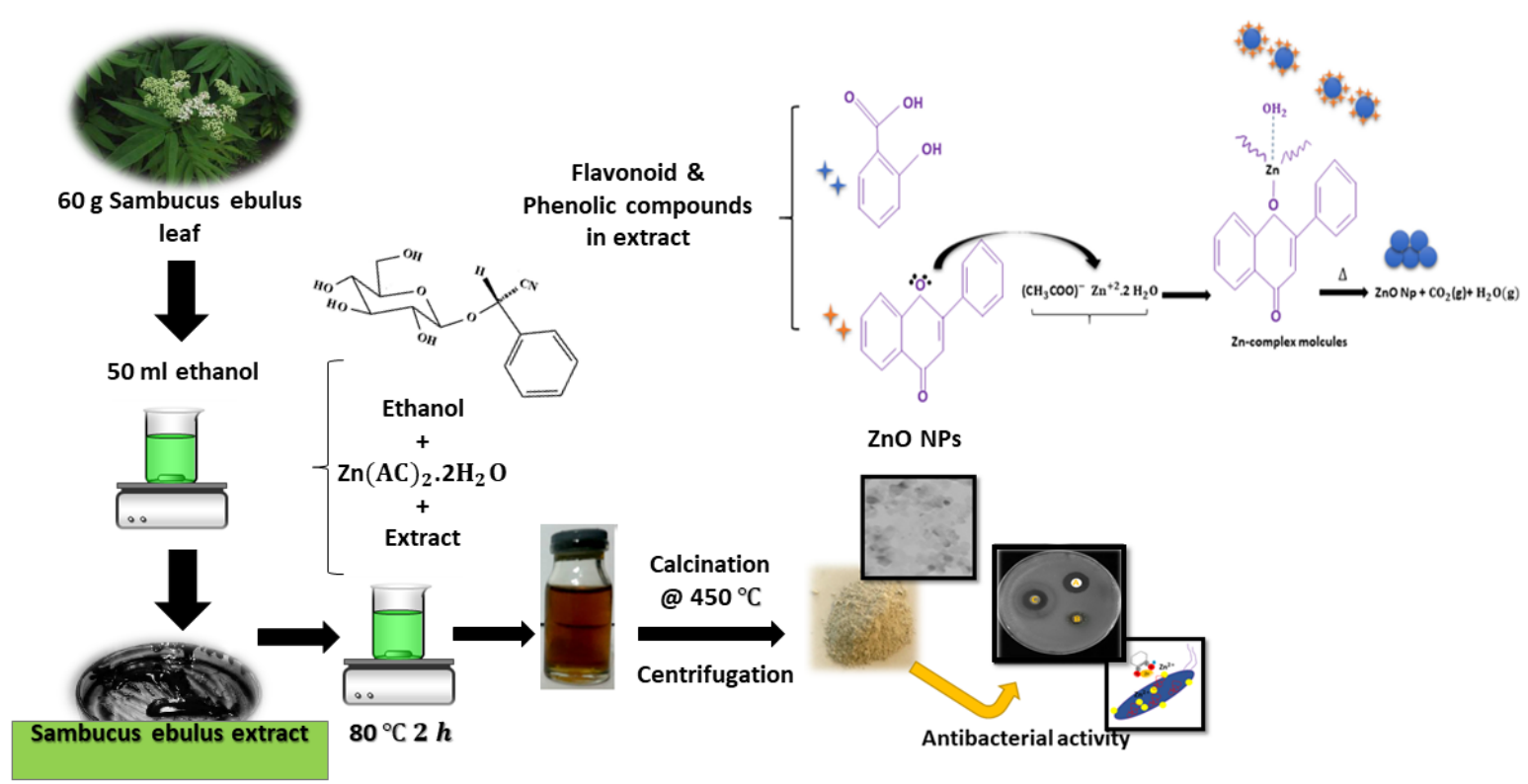

Figure 1. A schematic illustration of the synthetic route for production of $\mathrm{ZnO}$ nanoparticles (NPs).

\subsection{Antibacterial Activity Test}

The antibacterial activity of the biosynthesized ZnO NPs against pathogenic microorganisms, namely Gram-positive Bacillus cereus (KNIH28) and Staphylococcus aureus (ATCC6538 P), and Gramnegative Escherichia coli (E. coli)ATCC27853), was carried out on Muller-Hilton agar dishes using the disk diffusion method [45]. Nutrient agar broth (Himedia, Bombay) was used as bacterial culture medium in the bacterial assays. Pure cultures of the microorganisms were provided by the Alborz hospital, Karaj, Iran. The bacterial pathogens were freshly incubated for $4 \mathrm{~h}$ to standardize the culture to McFarland standards $\left(10^{6} \mathrm{CFU} / \mathrm{mL}\right)$.

All of the chemicals used for the cell culturing were of analytical grade. Cells were grown in agar media and humidified incubator at $37{ }^{\circ} \mathrm{C}$ under $5 \% \mathrm{CO}_{2}$. The concentration of bacterial cells was adjusted to $10^{6} \mathrm{CFU} / \mathrm{mL}$, and ciprofloxacin $(10 \mu \mathrm{g} / \mathrm{disc})$ was used as a standard. Paper disks $(6 \mathrm{~mm}$ diameter, Whatman No. 1 filter paper) infused with $100 \mu \mathrm{g} / \mathrm{mL}$ concentrations of prepared ZnO NPs and pure extract $(10 \mu \mathrm{g} / \mathrm{mL})$ suspended in deionized water were used to ascertain the antibacterial activity, followed by incubation at $37^{\circ} \mathrm{C}$ for a period of $24 \mathrm{~h}$. Inhibition zones, that formed around the disk, were investigated by measuring the corresponding diameter. The antibacterial experiments were repeated three times.

\subsection{Antioxidant Activity}

The antioxidant activity was determined using the hydrogen peroxide $\left(\mathrm{H}_{2} \mathrm{O}_{2}\right)$ free radical scavenging assay [46]. A quantity of $1 \mathrm{~mL}$ (with various concentrations) of the biosynthesized $\mathrm{ZnO}$ NPs and ascorbic acid as a standard were mixed with $50 \mathrm{mM}(0.6 \mathrm{~mL}) \mathrm{H}_{2} \mathrm{O}_{2}$ solution and then incubated at room temperature for $5 \mathrm{~min}$. Absorbance was detected with a UV-vis spectrophotometer at $230 \mathrm{~nm}$. 
Phosphate-buffered saline without $\mathrm{H}_{2} \mathrm{O}_{2}$ was used as a blank test [46]. The inhibition percentage of hydrogen peroxide scavenging was obtained using the following equation:

$$
\% \mathrm{H}_{2} \mathrm{O}_{2} \text { free radicals }=\left\{1-\left(\frac{A_{s}}{A_{c}}\right)\right\} \times 100
$$

where $A_{c}$ is the absorbance of the control and $A_{s}$ is the absorbance of the sample.

\subsection{Photocatalytic Activity}

The photocatalytic activity of the biosynthesized ZnO NPs was investigated via the photocatalytic degradation of $\mathrm{MB}$ (a dye normally resistant to biodegradation). The photocatalytic experiments were performed under UV light ( $24 \mathrm{~W}$ UV lamp, $360 \mathrm{~nm}$ ) irradiation. The photocatalytic decomposition of MB solution ( $50 \mathrm{ppm}$ ) by ZnO NPs as a photocatalyst $(0.02 \mathrm{~g})$ was performed in a $100 \mathrm{~mL}$ beaker at $35{ }^{\circ} \mathrm{C}$ under $\mathrm{UV}$ irradiation and continuous stirring to achieve the homogeneity of the solution. Absorbance was measured with a UV-Vis spectrophotometer.

\subsection{Analytical Methods}

The X-ray diffraction (XRD) pattern of ZnO NPs was recorded using a PANalytical PW3050/60 $\mathrm{X}$-ray diffractometer equipped with $\mathrm{Cu}-\mathrm{K} \alpha$ radiation source $(\lambda=1.5406 \AA)$ operated at $40 \mathrm{kV}$ and $30 \mathrm{~mA}$. Transmission electron microscopy (TEM; Philips CM120), field emission scanning electron microscopy (FE-SEM; Mira3 Tescan), energy-dispersive X-ray spectroscopy (EDX; Mira3 Tescan), and X-ray photoelectron spectroscopy (XPS; Thermo Scientific K-Alpha) were employed to investigate the morphology and topography of the samples along with elemental chemical surface analysis.

The FE-SEM instrument was operated at an accelerating voltage at $10 \mathrm{kV}$. The synthesized NPs were subjected to UV, Fourier-transform infrared (FTIR; range $4000-400 \mathrm{~cm}^{-1}$ ), and photoluminescence (PL; range 200-800 nm) spectroscopy (UV-visible spectrophotometer, PerkinElmer and Cary fluorescence spectrophotometer) to survey the optical properties, functional groups, and structural defects. An electron paramagnetic resonance (EPR) investigation on a Bruker ELEXSYS E500 X-band $(\sim 9.45 \mathrm{GHz})$ spectrometer was conducted to study the paramagnetic defects in the structure. The GC-MS analysis of the plant extract was conducted using an Agilent $7890 \mathrm{~A}$ instrument under computer control at $70 \mathrm{eV}$ that comprises an AOC-20i auto-sampler and a gas chromatograph interfaced to a mass spectrometer (GC-MS) equipped with an Agilent $5975 \mathrm{C}$ fused capillary column $(30 \times 0.25 \mu \mathrm{m}$ ID $\times 0.25 \mu \mathrm{m} \mathrm{df}$ ). For GC-MS detection, an electron ionization system was operated in electron impact mode with an ionization energy of $70 \mathrm{eV}$. Helium gas $(99.999 \%)$ was used as a carrier gas at a constant flow rate of $1 \mathrm{~mL} / \mathrm{min}$, and an injection volume of $2 \mu \mathrm{L}$ was employed (a split ratio of 10:1). The injector temperature was maintained at $260^{\circ} \mathrm{C}$. The ion-source temperature was kept at $270{ }^{\circ} \mathrm{C}$. The oven temperature was programmed from $40^{\circ} \mathrm{C}$ with an increase rate of $3{ }^{\circ} \mathrm{C} / \mathrm{min}$ to $250{ }^{\circ} \mathrm{C}$. Surface potential was investigated using a Malvern Zetasizer Nano-series (Malvern Instruments Zen 3600, Malvern, UK)

\section{Results and Discussion}

\subsection{Physicochemical Characterisation}

The XRD pattern of the biosynthesized ZnO NPs presented in Figure 2a reveals well-defined relatively broad peaks with high intensity which indicates the formation of nanocrystalline phase. The observed peaks are indexed within the hexagonal $\mathrm{ZnO}$ wurtzite-type structure, in agreement with Joint Committee on Powder Diffraction Standards (JCPDS) card no. 36-1451 [38]. No additional peaks can be detected within the resolution limit of the X-ray diffractometer, thereby confirming the formation of single $\mathrm{ZnO}$ phase. Using the Debye-Scherrer formula $(\mathrm{D}=0.9 \lambda / \beta \cos \theta$, where $\theta$ is the diffraction angle, $\lambda=1.5406 \AA$, and $\beta$ is the peak width at half maximum), crystallite size of prepared $\mathrm{ZnO}$ nanoparticles was calculated around $17 \mathrm{~nm}$ [38]; also, lattice parameters $(\mathrm{a}, \mathrm{c})$ were found to be about 3.306 and 5.199, respectively. 
The elemental information of the synthesized ZnO NPs was confirmed by EDX (Figure 2b); the spectrum indicates the existence of $\mathrm{Zn}$ and $\mathrm{O}$ elements which confirms again the purity of the prepared $\mathrm{ZnO}$ NPs.

The analysis of EPR curve based on the calculated g-values from a spectrum formed of a symmetrical Lorentzian shape, indicated the presence of two narrow resonances: one at g-value $~ 1.985$ and the other at g-value $\sim 1.987$, corresponding to shallow donors and singly ionized oxygen vacancies, respectively (Figure 2c) [47,48].
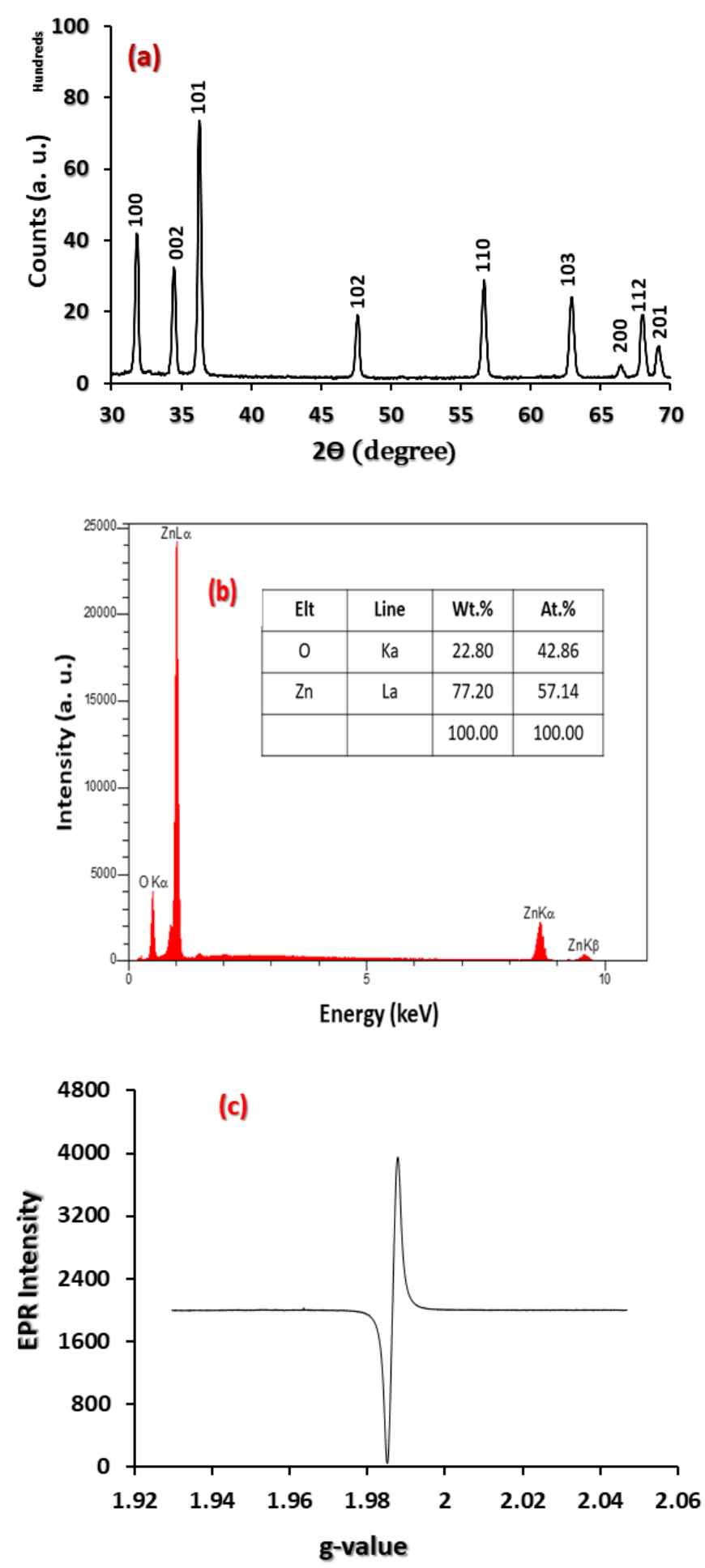

Figure 2. Cont. 

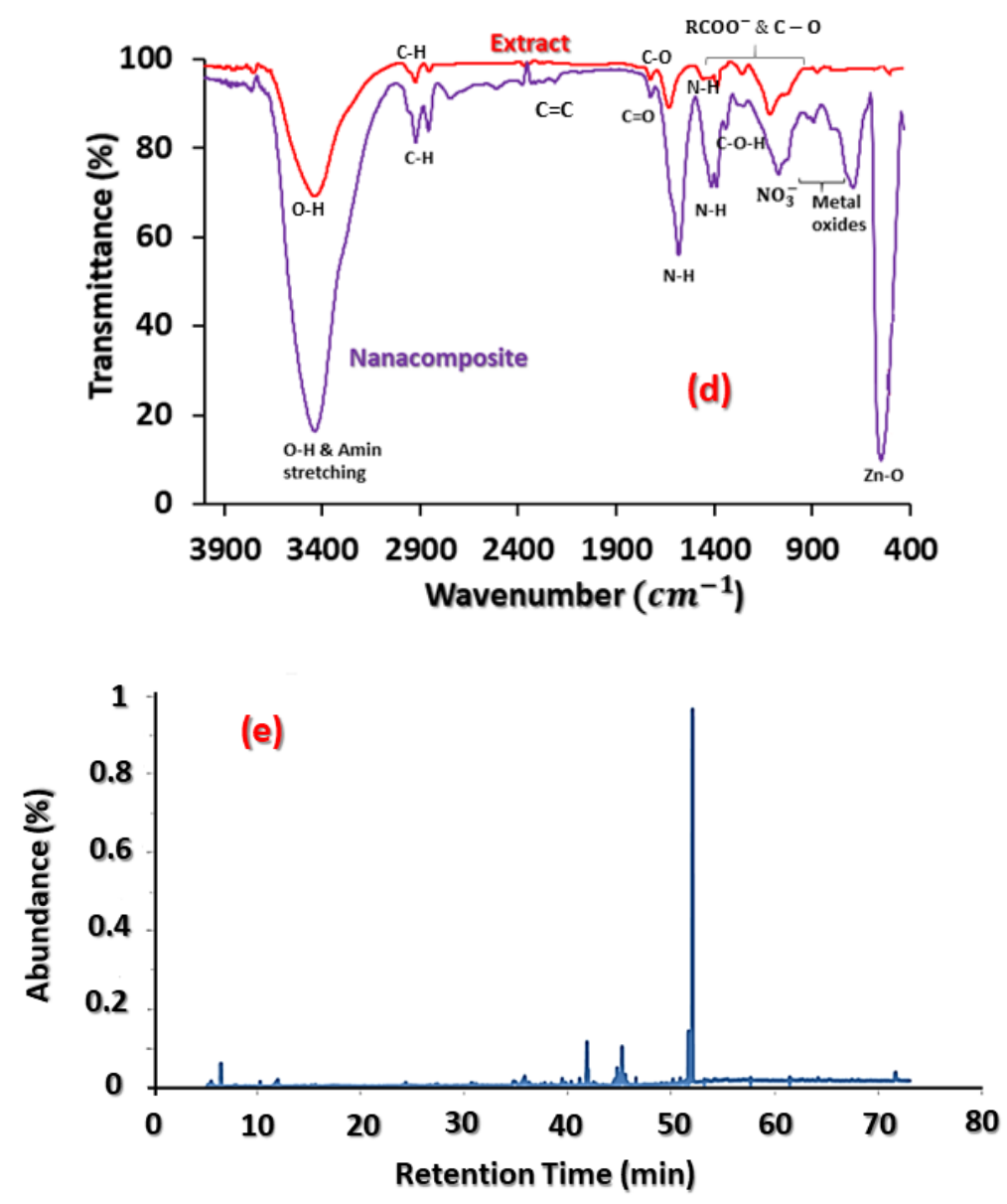

Figure 2. (a) X-ray diffraction pattern; (b) energy-dispersive $X$-ray spectroscopy spectrum; (c) electron paramagnetic resonance (EPR) of ZnO NPs; and (d) Fourier-transform infrared spectroscopy spectra of $\mathrm{ZnO}$ nanoparticles (purple line), S. ebulus extract (red line); and (e) typical chromatogram of the extract.

FTIR analysis helped to identify functional groups existing in the plant extract that contribute to the mechanism of bonding with ZnO NPs. As we mentioned previously, S. ebulus extract contains high amounts of polyphenolic derivatives. such as flavonoids, anthocyanins, and cyanidin-3-glucoside, which are considered potential bioactive compounds for therapeutic treatments and to act as reducing agents [8-15]. A comparison between the FTIR spectrum of the plant extract and that of the biosynthesized ZnO NPs is shown in Figure 2d. Accordingly, the FTIR spectrum of the plant extract exhibited several peaks at 3429, 2846, 2921, 1700, 1670, 1527, 1383, 1242, 1076, 1380, 1249, 1110, and $1024 \mathrm{~cm}^{-1}$. The peaks at $3429(\mathrm{O}-\mathrm{H}), 1527-1670(\mathrm{~N}-\mathrm{H})$, and $1076(\mathrm{C}-\mathrm{O})$ or 880-1380 (RCOO) $\mathrm{cm}^{-1}$ are related to alkaloids, flavonoids, and phenolic compounds, respectively [49-52], whereas the broad stretching band at $3429 \mathrm{~cm}^{-1}$ indicates the presence of hydrogen-bonded groups. These results signify the existence of flavonoid derivatives in the S. ebulus extract. Any shift or change in the position and intensity of peaks in the sample spectrum can be correlated with the interaction of the functional groups of the flavonoids and phenols with the ZnO NPs. It can be mentioned that functional groups in the extract donate electrons that could reduce zinc ions $\left(\mathrm{Zn}^{2+}\right.$ to $\left.\mathrm{Zn}^{+1}\right)$ and finally zinc NPs $\left(\mathrm{Zn}^{0}\right)$. Moreover, the negative functional groups present in the extract could have a stabilizing effect. FTIR spectra of the biosynthesized ZnO NPs showed a small shift with slight changes in some related peaks and in their intensities, suggesting that the major biomolecules from the extract were capped or bonded to the surface of $\mathrm{ZnO}$ NPs. The major peak for the plant extract shifting from 3429 to $3426 \mathrm{~cm}^{-1}$ in $\mathrm{ZnO}$ was assigned to the $\mathrm{O}-\mathrm{H}$ of the phenol groups and $-\mathrm{NH}_{2}$ stretching vibrations, while another peak shifted from 1668 to $1579 \mathrm{~cm}^{-1}$ was ascribed to N-H binding. The appearance of new peaks at 700 and 2212-2230 $\mathrm{cm}^{-1}$ proved that ZnO NPs underwent C-H and C=C out-of-plane bending, respectively. 
Furthermore, the FTIR spectrum of the biosynthesized ZnO NPs showed a sharp and intense band at $546 \mathrm{~cm}^{-1}$, indicating the existence of Zn-O vibrations [52]. The FTIR results demonstrated that phenol and flavonoid compounds were abundant in the prepared extract and ZnO NPs. In addition, according to the GC-MS technique and Table 1, the most important compounds in the extract were carbonyl acids, ethers, and phenolic compounds.

Table 1. Compounds contained in the alcoholic extract of S. ebulus.

\begin{tabular}{|c|c|c|c|c|c|}
\hline Compound & $\begin{array}{c}\text { Retention } \\
\text { Time (min) }\end{array}$ & $\%$ & Compound & $\begin{array}{l}\text { Retention } \\
\text { Time (min) }\end{array}$ & $\%$ \\
\hline Acetic acid & 5.50 & 1.20 & $\begin{array}{l}\text { 14-methyl-Pentadecanoic acid, } \\
\text { methyl ester }\end{array}$ & 41.12 & 0.67 \\
\hline 1,3-dimethoxy- Propane & 5.60 & 0.17 & n-Hexadecanoic acid & 41.81 & 9.3 \\
\hline 1-Butanol & 6.41 & 2.38 & Hexadecanoic acid, ethyl ester & 42.43 & 0.33 \\
\hline 1,1-diethoxy-2-Propanone & 11.68 & 0.66 & $\begin{array}{l}\text { 9Z,12Z-Octadecadienoic acid, } \\
\text { methyl ester }\end{array}$ & 44.39 & 0.36 \\
\hline Isovaleric acid & 12.01 & 3.52 & $\begin{array}{l}\text { 9Z,12Z,15Z-Octadecatrienoic } \\
\text { acid, methyl ester }\end{array}$ & 44.52 & 1.2 \\
\hline 4-vinylphenol & 24.27 & 1.6 & Phytol & 44.74 & 3.08 \\
\hline D(-)-Quinic acid & 34.76 & 0.32 & $\alpha$-Linilenic acid & 45.21 & 8.2 \\
\hline Pentanoic acid & 36.22 & 0.28 & Octadecanoic acid & 45.52 & 2.62 \\
\hline (-)-Loliolide & 41.03 & 0.42 & $\begin{array}{l}\text { 9Z,12Z,15Z-Octadecatrienoic } \\
\text { acid, ethyl ester, }\end{array}$ & 44.52 & 0.9 \\
\hline Neophytadiene & 39.421 & 1.02 & Mono(2-ethylhexyl) phthalate & 52.02 & 51.41 \\
\hline $\begin{array}{l}\text { 9-Methyl-3,4-dihydro-2H- } \\
\text { pyrido(1,2-a)pyrimidin-2-one }\end{array}$ & 39.76 & 2.50 & Octadecanoic acid (stearic acid) & 45.52 & 2.57 \\
\hline $\begin{array}{l}\text { 14-methyl-Pentadecanoic } \\
\text { acid, methyl ester }\end{array}$ & 41.12 & 0.80 & D-alpha-Tocopherol(Vitamin E) & 64.15 & 0.69 \\
\hline Lignocaine & 41.03 & 0.42 & 22,23 -dihydro Stigmasterol & 71.65 & 3.38 \\
\hline
\end{tabular}

There are many advantages of applying natural plants in NP synthesis, including coating NPs with different pharmacological species (such as phenolic and polyphenolic compounds) on the metal oxide layer, which facilitates the bonding of NPs with the receivers on bacterial membranes. The S. ebulus extract is rich in such compounds, which are responsible for enhancing the antibacterial properties of $\mathrm{ZnO}$ NPs. The possible mechanism for the formation of ZnO NPs using the plant extract could be related to the flavonoid/phenolic molecules reacting with $\mathrm{Zn}^{2+}$ ions through the donor-acceptor mechanism. Oxygen or hydroxyl compounds present in the plant extract tend to donate an electron to electrophile $\mathrm{Zn}$ complexes resulting in oxidation of $\mathrm{OH}$ groups and reduction of electron deficient zinc ions to zinc atoms (Figure 1).

The synthesized NPs were investigated by XPS surface analysis; Figure 3 depicts a full survey scan in the range $0-1100 \mathrm{eV}$. Two intense peaks located at 1024 and $1044 \mathrm{eV}$ were observed, which are attributed to the $\mathrm{Zn} 2 p_{3 / 2}$ and $\mathrm{Zn} 2 p_{1 / 2}$, respectively, corresponding to $\mathrm{Zn}-\mathrm{O}$ bonding within the hexagonal wurtzite-type structure $[53,54]$. The O1s peak was also present in the spectrum at $\sim 529-530 \mathrm{eV}$, corresponding to $\mathrm{Zn}-\mathrm{O}$ bonds in the intrinsic sites of the $\mathrm{ZnO}$ matrix, which is in good agreement with the FTIR spectrum of the biosynthesized ZnO NPs (sharp and intense band at $546 \mathrm{~cm}^{-1}$, which indicates the existence of $\mathrm{Zn}-\mathrm{O}$ vibrations). 


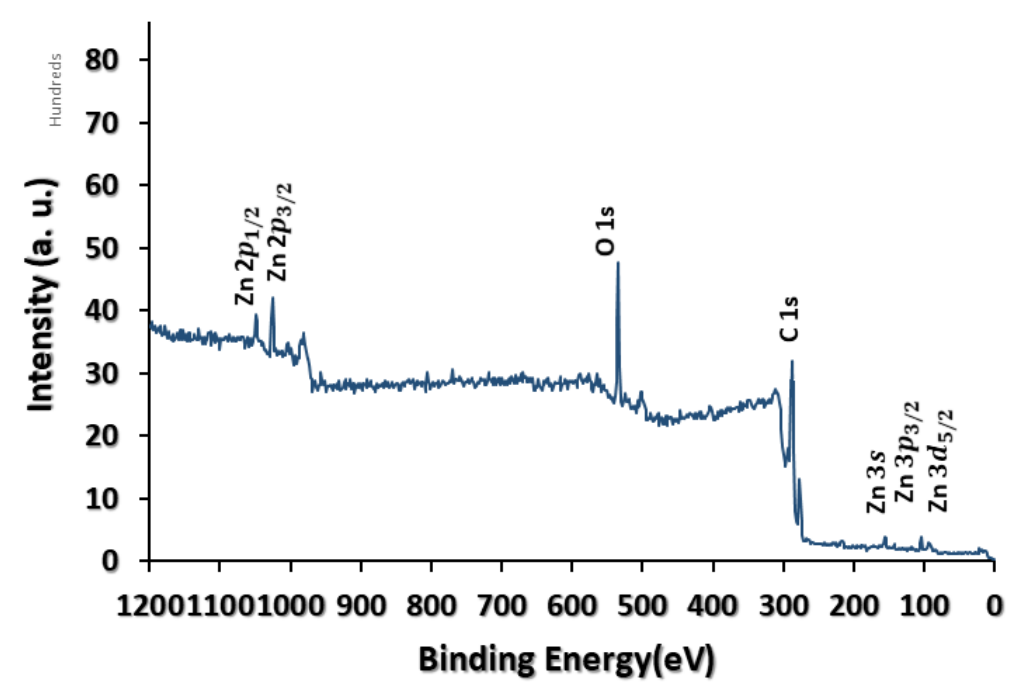

Figure 3. X-ray photoelectron spectroscopy spectrum of the biosynthesized ZnO NPs.

\subsection{Optical Characterisation}

Figure 4a shows the absorption spectrum of the biosynthesized $\mathrm{ZnO}$ NPs with an absorption peak at around $376 \mathrm{~nm}$, which was assigned to the band-gap absorption of $\mathrm{ZnO}$, while the very weak peak at $350 \mathrm{~nm}$ could be related to the presence of $S$. ebulus leaf extract. The energy band gap was found to be $\sim 3.3 \mathrm{eV}$ using the formula $\mathrm{E}=\mathrm{hc} / \lambda$, where $\lambda$ is the wavelength, $\mathrm{h}=6.626 \times 10^{-34} \mathrm{Js}$ (Plank's constant), and $\mathrm{c}=3 \times 10^{8} \mathrm{~m} / \mathrm{s}$, which is in good agreement with the reported values in the literature [42,44].

Moreover, using UV-vis diffuse reflectance spectroscopy (Figure $4 \mathrm{~b}$ ), the band-gap energy of the biosynthesized ZnO NPs was calculated using the Kubelka-Munk equation [55]:

$$
\mathrm{F}(\mathrm{R})=\frac{(1-R)^{2}}{2 R}
$$

where $\mathrm{R}$ is the reflectance. By plotting $(F(R) \times E)^{1 / 2}$ as a function of energy, the value of the band gap was obtained to be $\sim 3.3 \mathrm{eV}$ (Figure $4 \mathrm{~b}$ ). The strong absorption in the UV region demonstrated that the biosynthesized ZnO NPs has a good capacity for UV-protection applications [24]. For example, the skin is one of the important protective barriers of the body and various events, such as trauma, cuts, and burns, can damage this natural layer. In these cases, a special cover must be used in the process of wound healing to repair the skin, improve the wound, protect it from UV rays, and reduce the risk of wound infection.

The PL spectrum of ZnO normally consists of two main emission peaks: (1) a UV peak near the band-edge emission and (2) a visible peak resulting from deep level emission (DLE) bands [38,56]. Some optically active intrinsic defects influence the optical properties of $\mathrm{ZnO}$, and different kinds of defects are created during synthesis, growth, and/or upon annealing. The PL spectra of bare $\mathrm{ZnO}$ and biosynthesized $\mathrm{ZnO}$ using the plant extract are shown in Figure $4 \mathrm{c}, \mathrm{d}$, respectively. A broad blue emission peak centered at $\sim 478 \mathrm{~nm}$ can be observed for the bare $\mathrm{ZnO}$, which is normally associated with $\mathrm{Zn}$ defects, such as transitions from $Z n_{i}$ levels (or conduction band) to valence band or $V_{Z n}$ states (Figure 4c), while in Figure 4d, the PL spectrum of the biosynthesized $\mathrm{ZnO}$ using the plant extract is composed of a weak UV band at around $402 \mathrm{~nm}$ and an intense orange band at around $598 \mathrm{~nm}$. UV emission is related to near band-edge transition, exciton-exciton collision, and free exciton recombination. The UV emission is attributed to transitions between $Z n_{i}$ to the valence band [38], while yellow-orange emission is generally attributed to the DLE bands and excess oxygen, such as the transition between the vacancies and interstitials of neutral and singly ionized oxygen [38]. In n-type $\mathrm{ZnO}$, acceptor-like defects $\left(O_{i}\right)$ are easier to form, which enables the transition between different band-gap energies. Yellow-orange luminescent materials are widely used in optical and medical 
treatments, and luminescent nanoproducts with potential bio-applications have gained great interest during the past years [57]. It can be concluded that during the chemical interaction between the plant extract molecules and ZnO NPs, some defects were passivated, which influenced the defect density and emission properties. As we mentioned previously, S. ebulus extract is rich in antioxidants (such as phenols and flavonols) through their carboxyl groups with binding to ZnO NPs, which can produce new levels or defects in the band gap of the host structure and, finally, influence the emission of $\mathrm{ZnO}$. It is worth mentioning that many hundred years ago, Sambucus ebulus extract was used as a natural dye for textile applications; it is reported that silk fabrics were dyed successfully sing natural dyes extracted from Sambucus ebulus fruit [55].
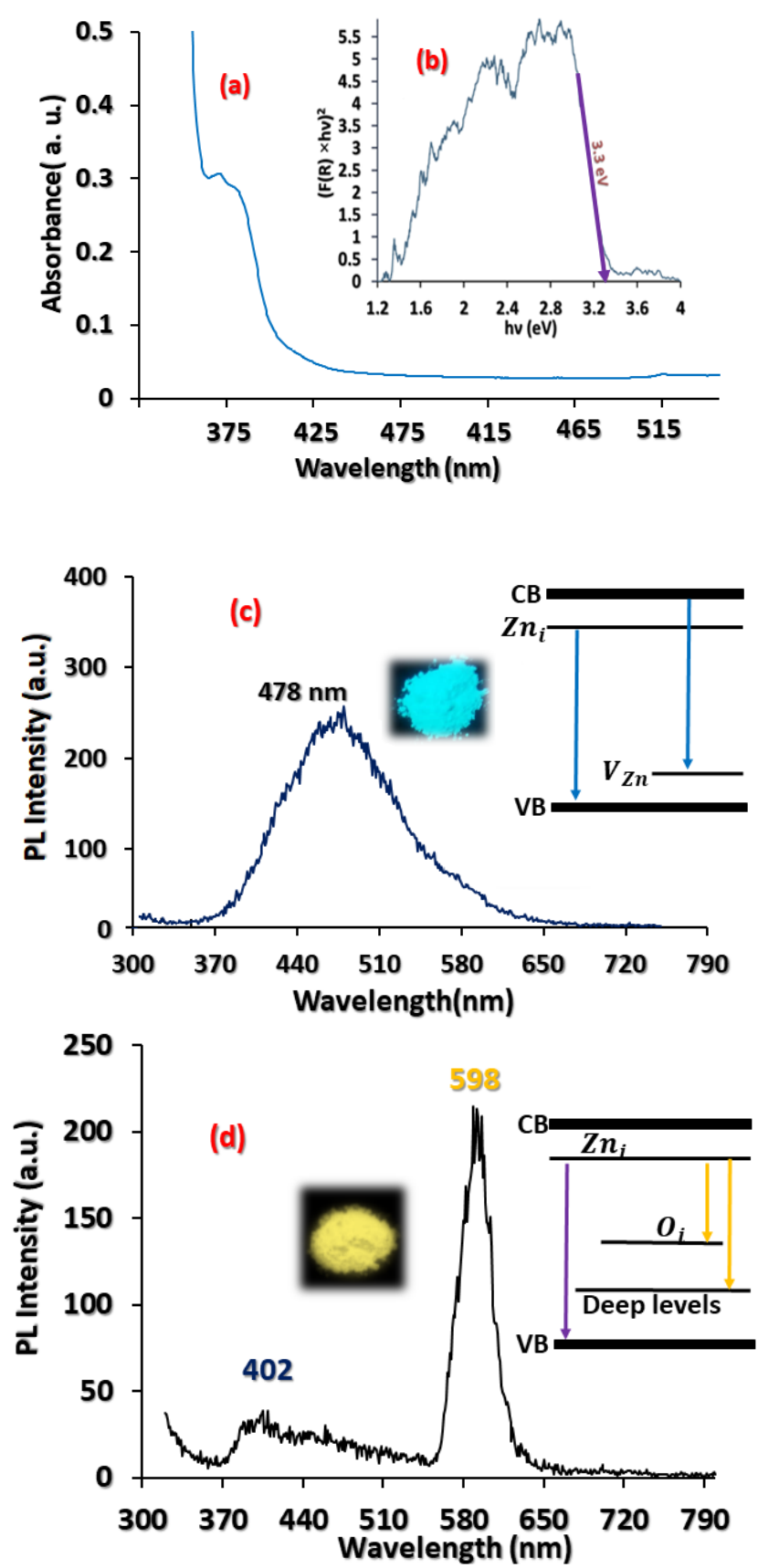

Figure 4. (a) UV absorbance and (b) optical energy band gap energy of the biosynthesized ZnO NPs using S. ebulus leaf extract. Photoluminescence spectra of (c) bare $\mathrm{ZnO}$ and (d) the $\mathrm{ZnO}$ nanoparticles. 


\subsection{Microstructural Characteristisation}

The uniform distribution and almost spherically shaped ZnO NPs can be observed in the FE-SEM image in Figure 5a. Some NPs are present with a hexagonal shape and the average particle size is around 40-45 nm. The NPs were dispersed in ethanol and sonicated in an ultrasonic bath for $20 \mathrm{~min}$ for TEM analysis. The TEM image in Figure $5 b$ clearly shows that the NPs are mostly spherical with a size ranging from 25 to $30 \mathrm{~nm}$. The selected area electron diffraction pattern, depicted in Figure 5b, confirms the crystalline nature of the biosynthesized $\mathrm{ZnO}$ NPs.
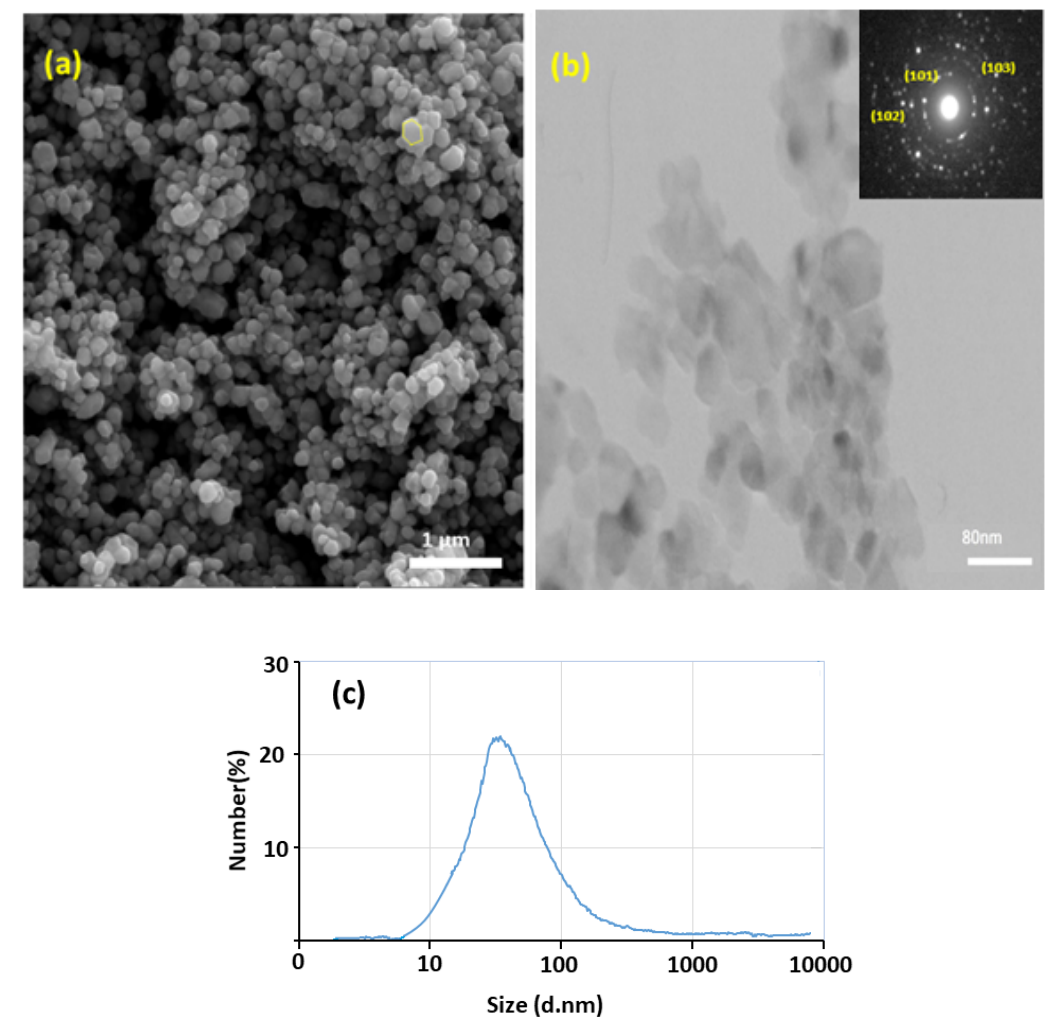

Figure 5. (a) Field emission scanning electron microscopy and (b) transmission electron microscopy images, and (c) size distribution by dynamic light scattering of the biosynthesized ZnO NPs.

According to the dynamic light scattering (DLS) technique (Figure 5c), the average size of the NPs is around $65 \pm 4 \mathrm{~nm}$.

It is known that the physicochemical properties of nanomaterials, including size, shape, surface area, zeta potential, and composition greatly effect on their toxicological effects. In this regard, ZnO NPs induce a significant cytotoxicity in a size-dependent trend; particularly soluble and smaller NPs provide more useful toxicological information on nanomaterials. ZnO-NP antimicrobial activity is significantly affected by particles' morphology and size, as well as concentration. The smaller the NP size, the higher their toxic effects on microorganisms, which have relatively large interfacial area and can easily penetrate bacterial membranes, thereby increasing their antibacterial effectiveness. The biosynthesized $\mathrm{ZnO}$ NPs used in the present work present an average diameter of 55-75 nm. It is reported that spherical shape nanoparticles (with average $21 \mathrm{~nm}$ size) were obtained using plant extract of Ocimum americanum, which showed significant antimicrobial activity against Gram-positive, Gram-negative, and fungal pathogens [24]. ZnO NPs prepared using aqueous Tabernaemontana divaricata green leaf extract showed a spherical shape with particle size ranging from 20 to $50 \mathrm{~nm}$ [25]. A higher antibacterial activity against $S$. aureus and E. coli and lesser antibacterial activity against Salmonella Paratyphi (S. paratyphi) compared to the standard pharmaceutical formulation, was also observed. ZnO NPs prepared using pomelo fruit juice with an average particle size of about 10-20 nm showed significant antibacterial 
activity against pathogenic strains such as $S$. aureus and K. aerogenes and a less significant role in E. coli pathogenic bacterial strains [26]. ZnO NPs green synthesized from Aristolochia indica of size $22.5 \mathrm{~nm}$ exhibited remarkable bactericidal activity [27].

A zeta-potential study was carried out to detect the surface charge and stability of the prepared NPs and indicated the presence of a distinct peak at $-38 \mathrm{mV}$, which suggests that the synthesized NPs have good stability. This means that the capping molecules present on the surface of biosynthesized ZnO NPs are mainly comprised of negatively charged groups and also responsible for moderate stability of the nanoparticles. The rich source of proteins and flavonoids in the extract may be responsible for the reduction of metal ions and efficient stabilization of $\mathrm{ZnO} N P s$.

\subsection{Photocatalytic Tests}

Photocatalytic technology is an important technique for eliminating dyes in sewage water. The photocatalytic degradation characteristics of the biosynthesized NPs in MB dye solution was conducted under UV irradiation. Under irradiation, electrons through the valence band are excited and travel to the conduction band, which creates holes in the valence band. Generally, the electrons form $\mathrm{O}_{2}^{-}$species through reaction with oxygen, while the holes form hydroxyl radicals through reaction with $\mathrm{OH}$ ions. Hence, oxidizing species can attack and oxidize organic pollutants. Usually, the proper photocatalytic activity of $\mathrm{ZnO}$ products can be related to the number of defects [58,59].

The degradation rate of MB was calculated as follow [60]:

$$
\text { degradation } \%=\left(\mathrm{A}_{0}-\mathrm{A}\right) / \mathrm{A}_{0} \times 100
$$

where $\mathrm{A}_{0}$ is the absorbance at $\mathrm{t}=0 \mathrm{~min}$ and $\mathrm{A}$ is the absorbance after treatment. According to Figure $6 a$, it is obvious that the absorbance peak was reduced significantly (after $200 \mathrm{~min}$ ). Indeed, the biosynthesized ZnO NPs show a noticeable reduction in intensity, thus indicating the degradation of the dye molecules. Figure $6 \mathrm{~b}$ depicts the degree of degradation of the MB solution obtained with $\mathrm{ZnO} N P s$ after UV radiation over time. It is obvious that the maximum degradation of around $80 \%$ was obtained after $200 \mathrm{~min}$. In a similar study on photocatalytic degradation of $\mathrm{MB}$ dye with $\mathrm{ZnO}-$ Camellia sinensis NPs, the same result of approximately 80\% degradation in 120 min was obtained [61].
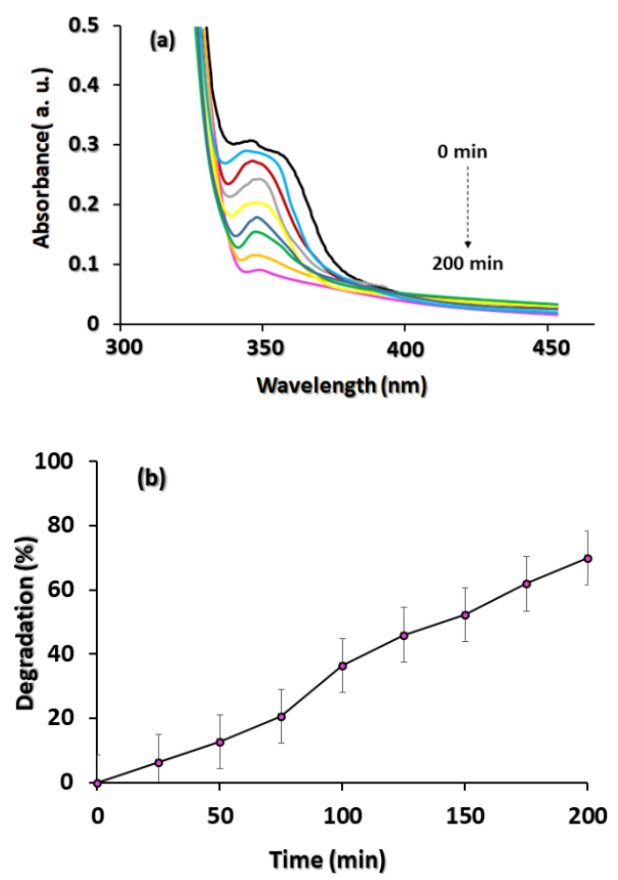

Figure 6. (a) UV absorption spectra (black line: $0 \mathrm{~min}$ to purple line: $200 \mathrm{~min}$ in $25 \mathrm{~min}$ increments) and (b) degradation percentage of methylene blue (50 ppm) by photocatalysis with the biosynthesized ZnO NPs under UV irradiation. 


\subsection{Antibacterial and Antioxidant Properties}

Since no previous work has been reported yet on S. ebulus extract-loaded ZnO NPs, some antibacterial properties in this study were compared with similar studies but using different natural extracts and commercial/chemical synthesized $\mathrm{ZnO}$ [62-83]. The antibacterial activity of the biosynthesized $\mathrm{ZnO}$ NPs using leaf extract and the pure extract was investigated on B. cereus, S. aureus, and E. coli bacteria (Figure 7a). The biosynthesized ZnO NPs exhibited antibacterial activity over all three bacteria, but was higher for Gram-negative bacteria compared to Gram-positive bacteria. Moreover, the ZnO NPs exhibited a considerable zone of inhibition for E. coli and B. cereus compared with S. aureus. Similar observations were reported for the antibacterial properties of $\mathrm{ZnO}$ NPs/plant extracts against $E$. coli strains $[62,63]$. The results show more activity toward Gram-negative bacteria, which can be due to the existence of a thick rigid layer that surrounds their cells. This effect has already been reported [63].
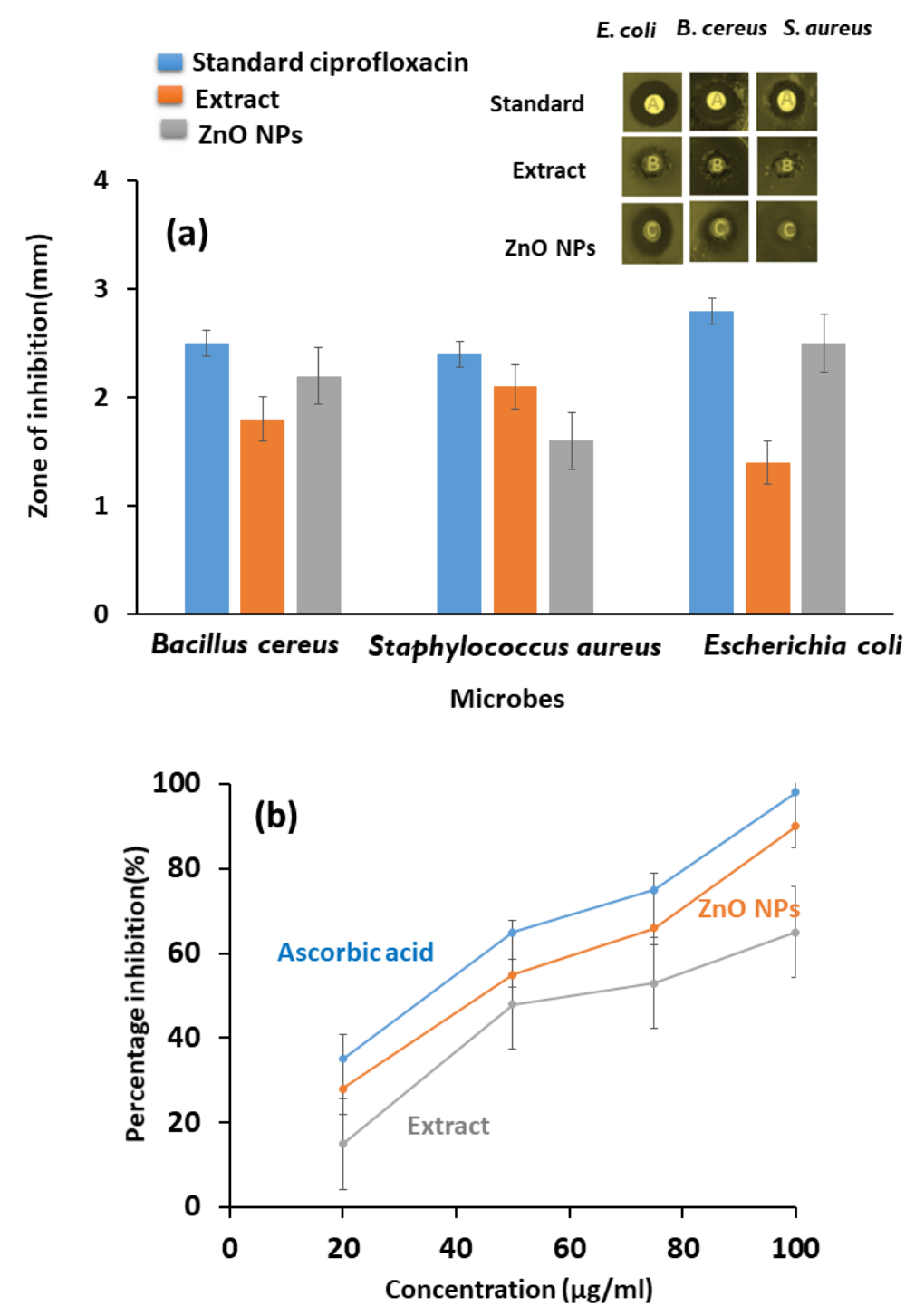

Figure 7. Cont. 


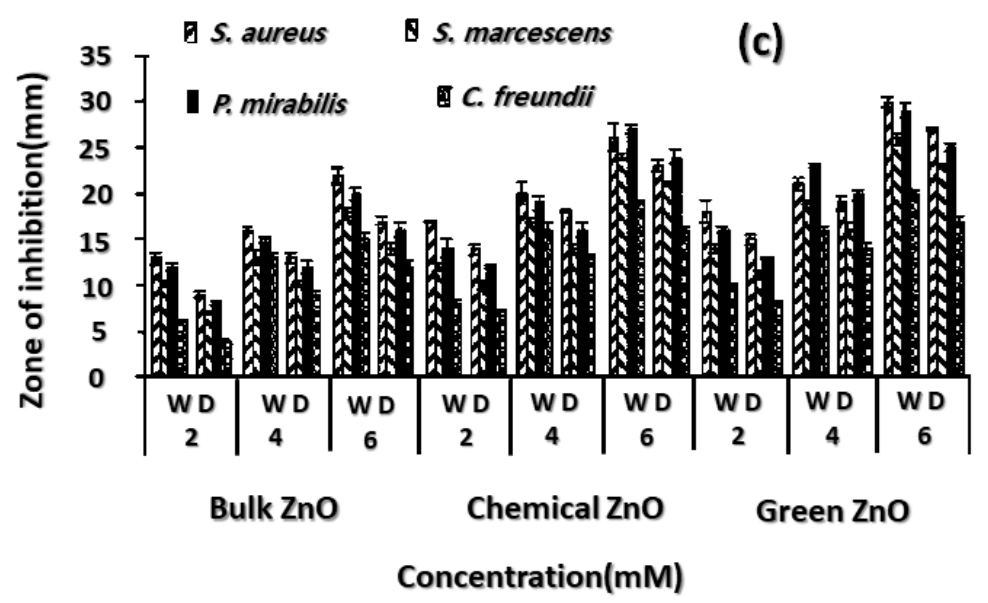

Figure 7. (a) Antibacterial activity of the biosynthesized ZnO NPs, S. ebulus extract, and ciprofloxacin against $B$. cereus, $S$. aureus, and E. coli, (b) $\mathrm{H}_{2} \mathrm{O}_{2}$ free radical scavenging activity of the biosynthesized $\mathrm{ZnO}$ NPs, S. ebulus extract, and ascorbic acid, and (c) antibacterial activity against various pathogens of green synthesized ZnO NPs when compared to chemical ZnO NPs [83].

The antioxidant properties of the biosynthesized NPs are presented in Figure $7 \mathrm{~b}$. The $\mathrm{H}_{2} \mathrm{O}_{2}$ activity of ascorbic acid (standard), the biosynthesized $\mathrm{ZnO}$ NPs, and leaf extract exhibited $\mathrm{IC}_{50}$ values of 36, 43, and $62 \mu \mathrm{g} / \mathrm{mL}$, respectively. Enhancement in the antioxidant properties of the biosynthesized $\mathrm{ZnO}$ NPs in comparison with the leaf extract could be a consequence of metal or $\mathrm{Zn}$ ions existing in the structure. Generally, it has been reported that phenolic species existing in plant extracts have revealed high antioxidant properties, which is an important characteristic for bio-applications [76]. For comparison, strong antioxidant activity has been found in ZnO NPs isolated from extracts of Allium sativum, Rosmarinus officinalis, and Ocimum basilicum for comparison [77].

Microorganisms are protected by a cell membrane covering them and through this membrane sufficient nutrient are transported [64,65]. Figure 8 shows different mechanisms adopted by Gramnegative bacteria for attachment of ZnO NPs and their transport inside the bacteria cell. Gram-negative bacteria have a triple thin layer of peptidoglycan compared with Gram-positive bacteria and show less toleration to nanoparticle interaction with the cell membrane. According to Figure 8, a Gram-negative bacterium (such as E. coli) has a layer of peptidoglycan in its cell wall where porins are present in the outer layer. Porins are a family of proteins that exist in the outer peptidoglycan layer that helps passive diffusion of NPs inside the cell. ZnO NPs prefer to dissolve in the aqueous medium containing bacteria and release $\mathrm{Zn}^{2+}$ ion (because of free energy) [78]. The interaction between zinc ions and the cell wall results in a change in surface tension which leads to the membrane depolarization at the point of contact. As a result, the bacterial membrane shows abnormal textures such as membrane rupture or membrane blebs. ZnO NPs, as an antibacterial agent, act with a series of mechanisms; in this way, cell membrane integrity loss (induced by disruption of the phospholipid bilayer) and oxidative stress (induced by reactive oxygen species (ROS) generation which causes cell death by inhibiting) are two important events (Figure 8) [64,79]. ZnO and its related defects can be easily activated by UV and visible light, which leads to electron-hole pair generation [35]; the formed excitons could increase ROS concentration. ROS molecules could be superoxide, hydroxyl, singlet oxygen, and peroxide ions which are produced on the surface of NPs and possess high electronegativity that can enhance the antimicrobial activity. For example, the generated $\mathrm{H}_{2} \mathrm{O}_{2}$ molecules can penetrate into the bacterial cell membrane inducing structural changes to membranes and hence disturbing nutrient/protein transport and causing bacteria death. $\mathrm{OH}$ radicals are negatively charged, and thus cannot penetrate the outer cell membrane of $E$. coli, which is also negatively charged, and remain in direct contact with the outer surface of the bacterium [66-68]. The entry of ZnO NPs into the cell leads to integrity loss of phospholipid layer and blebbing of intracellular elements resulting in cell death. Nanoparticles react with membrane proteins and inactivate them decreasing membrane permeability and causing cell 
death. The antibacterial activities of ZnO NPs strongly depend on shape, size, powder concentration, specific surface area, zeta potential, etc. For example, it is reported that ZnO NPs with positive surface potential showed higher antimicrobial properties compared with ZnO NPs of the same size but with negative surface potential [80]. Furthermore, it is reported that small-sized nanoparticles can penetrate the bacterial membrane easily and spherically shaped $\mathrm{ZnO}$ NPs release $\mathrm{Zn}^{2+}$ ions more effectively than rod-shaped ions $[81,82]$.

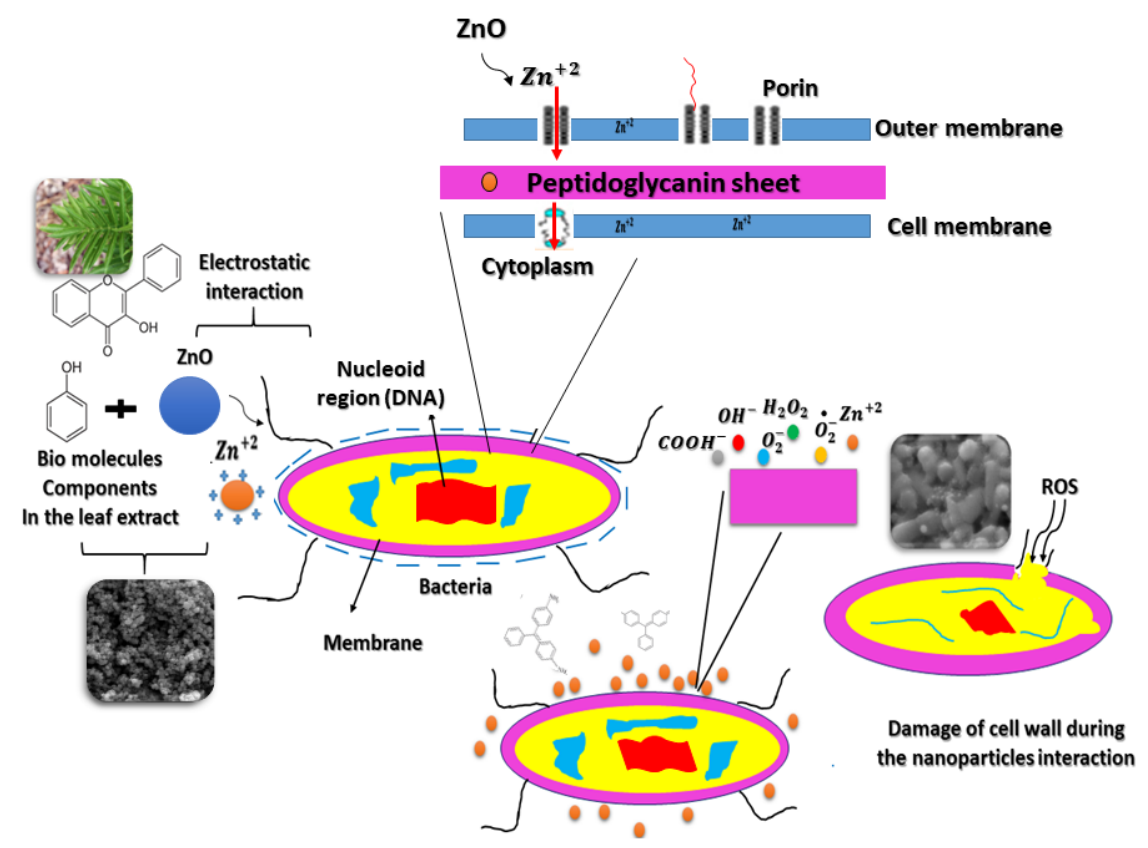

Figure 8. A schematic diagram of the antibacterial activity mechanism.

As observed above, biosynthesized $\mathrm{ZnO}$ NPs depict better antibacterial activity against various microorganisms when compared to pure extract.

Previous studies imply that green $\mathrm{ZnO}$ nanoparticles showed more enhanced biocidal activity against various pathogens when compared to chemical $\mathrm{ZnO}$ nanoparticles [83]; furthermore, Susheela et al. reported that green synthesized nanoparticles show more effective antimicrobial activity than those of plant extracts [84].

Surface modifying reagent molecules result in differences in the release of $\mathrm{Zn}^{2+}$ ions and the production of reactive oxygen species (ROS). S. ebulus leaf extract contains enormous numbers of carbonyl, carboxyl, and hydroxyl groups in polyphenols and flavonoids [35,69-71]. These compounds can have a positive effect on human health because they can act as antioxidants and anti-inflammatory and anticancer agents. Indeed, these compounds present a wide range of biological activities, and the presence of abundant hydroxyl and carbonyl groups is responsible for antibacterial applications [69-71]. These compounds can affect the release of $\mathrm{Zn}^{2+}$ and the production of ROS. The existence of these compounds in the extract and the surface helps $\mathrm{ZnO}$ NPs to adhere to the bacterial cell membranes. The chemical interaction between the extract molecules and ZnO NPs enhance the reactivity of NPs and improves penetration via bonding to the surface of the bacteria. Plant extract compounds attach to the surface of the bacteria and create new pathways near the surface for better transportation of or penetration by ions. For example, hydrogen in these compounds acts as both an oxidizing and a reducing agent (due to its two distinct oxidation states) which can easily form many bonds with other molecules [72,73].

In a recent study, it was found that Albizia lebbeck stem bark increased the antibacterial effect of biosynthesized ZnO NPs [74]. In another investigation, ZnO NPs (100-190 nm) were synthesized using Trifolium pratens flower extract and the high zone of their growth inhibition (29-31 mm) against E. coli, and S. aureus at $\sim 1200 \mu \mathrm{g} / \mathrm{mL}$ was obtained [20]. In the work performed by Gunalan et al. [75], 
the biosynthesized ZnO NPs using Aloe vera extract showed enhanced antibacterial properties compared with chemically prepared ZnO NPs [75]. On the other hand, Arvanag et al. [76] synthesized ZnO NPs with Silybum marianum L. seed extract and reported effective growth inhibition of Gram-negative E. coli. In another study, silver-loaded $\mathrm{ZnO}$ nanowires were synthesized under UV light and exhibited strong antibacterial effects against $E$. coli [73]; it was found that UV exposure caused more ROS species formation that increased antibacterial activity. In our study, we achieved lower used concentration values of S. ebulus leaf extract-loaded ZnO NPs that exhibited more effective antimicrobial activity against E. coli. It should be mentioned that despite the novel properties of Sambucus ebulus, similar to many kinds of plants, they may exhibit toxicity when large amounts of them are used [18]. Briefly, it can be concluded that combining ZnO NPs with S. ebulus extract is a simple, safe, and cost-effective approach for producing new materials with great potential for future biomedical and industrial applications.

\section{Conclusions}

In this study, ZnO NPs were successfully prepared through a green synthesis method using S. ebulus leaf extract, which showed interesting properties. X-ray diffraction analysis confirmed the formation of a $\mathrm{ZnO}$ hexagonal wurtzite structure with a crystallite size of $17 \mathrm{~nm}$. The prepared $\mathrm{ZnO} N P s$ exhibited high UV absorbance, strong orange emission at room temperature, and acceptable photocatalytic degradation of MB dye pollutant. Moreover, the prepared ZnO NPs demonstrated efficient antibacterial and antioxidant activities. Surface modifying reagent molecules from the extract resulted in better antibacterial activity, which may be due to the differences in the release of $\mathrm{Zn}^{2+}$ ions and the production of reactive oxygen species. The results of our investigation demonstrated that biosynthesized $\mathrm{ZnO}$ NPs possess promising potential in medical care, food packaging, and industrial applications as an alternative to chemical compounds. Further experiments should be performed, including in vivo measurements, and side effects of ingesting this compound should be thoroughly investigated.

Author Contributions: S.A. and H.-H.P. writing—original draft preparation; M.S.G., C.L., W.H. and M.J.T. writing-review and editing; H.A. and M.H.M.A. data curation. All authors have read and agreed to the published version of the manuscript.

Funding: This research was funded by Ministry of Science and ICT (2018M3D1A1058536). This work was also funded by the Korea government (MSIT) (No. 2019R1A2C2087604), and by the third Stage of Brain Korea 21 Plus Project in 2018.

Acknowledgments: This research was funded by Ministry of Science and ICT (2018M3D1A1058536). This work was also funded by the Korea government (MSIT) (No. 2019R1A2C2087604), and by the third Stage of Brain Korea 21 Plus Project in 2018.

Conflicts of Interest: The authors declare no conflict of interest.

\section{References}

1. Yusof, H.M.; Mohamad, R.; Zaidan, U.H.; Rahman, N.A.A. Abdul Rahman, Sustainable microbial cell nanofactory for zinc oxide nanoparticles production by zinc-tolerant probiotic Lactobacillus plantarum strain TA4. Microb. Cell Fact. 2020, 19, 1-17.

2. Podasca, V.-E.; Damaceanu, M.-D. Photopolymerized Films with ZnO and Doped ZnO Particles Used as Efficient Photocatalysts in Malachite Green Dye Decomposition. Appl. Sci. 2020, 10, 1954. [CrossRef]

3. Oh, S.; Kim, J. Correlation between the Morphology of ZnO Layers and the Electroluminescence of Quantum Dot Light-Emitting Diodes. Appl. Sci. 2019, 9, 4539. [CrossRef]

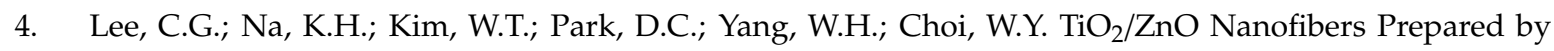
Electrospinning and Their Photocatalytic Degradation of Methylene Blue Compared with $\mathrm{TiO}_{2} \mathrm{Nanofibers}_{\text {. }}$ Appl. Sci. 2019, 9, 3404. [CrossRef]

5. Khan, H.; Sakharkar, M.; Nayak, A.; Kishore, U.; Khan, A. Nanoparticles for Biomedical Applications: An Overview; Elsevier Ltd.: Amsterdam, The Netherlands, 2018; pp. 357-377.

6. Vinardell, M.P.; Llanas, H.; Marics, L.; Mitjans, M. In Vitro Comparative Skin Irritation Induced by Nano and Non-Nano Zinc Oxide. Nanomaterials 2017, 7, 56. [CrossRef] 
7. Hernández, R.; Hernández-Reséndiz, J.R.; Martínez-Chávez, A.; Velázquez-Castillo, R.; Escobar-Alarcón, L.; Esquivel, K. X-ray diffraction Rietveld structural analysis of Au-TiO2 powders synthesized by sol-gel route coupled to microwave and sonochemistry. J. Sol-Gel Sci. Technol. 2020, 93, 1-14. [CrossRef]

8. Mazhdi, M.; Tafreshi, M. The effects of gadolinium doping on the structural, morphological, optical, and photoluminescence properties of zinc oxide nanoparticles prepared by co-precipitation method. Appl. Phys. A 2018, 124, 863. [CrossRef]

9. Kołodziejczak-Radzimska, A.; Jesionowski, T. Zinc oxide-from synthesis to application: A review. Materials 2014, 7, 2833-2881.

10. Abdolhoseinzadeh, A.; Sheibani, S. Enhanced photocatalytic performance of Cu2O nano-photocatalyst powder modified by ball milling and ZnO. Adv. Powder Technol. 2020, 31, 40-50. [CrossRef]

11. Yusof, H.M.; Mohamad, R.; Zaidan, U.H. Microbial synthesis of zinc oxide nanoparticles and their potential application as an antimicrobial agent and a feed supplement in animal industry: A review. J. Anim. Sci. Biotechnol. 2019, 10, 57. [CrossRef] [PubMed]

12. Awwad, A.M.; Amer, M.W.; Salem, N.M.; Abdeen, A.O. Green synthesis of zinc oxide nanoparticles (ZnO-NPs) using Ailanthus altissima fruit extracts and antibacterial activity. Chem. Int. 2020, 6, 151-159.

13. Yuan, H.; Ma, Q.; Ye, L.; Piao, G. The traditional medicine and modern medicine from natural products. Molecules 2016, 12, 559. [CrossRef] [PubMed]

14. Sruthi, S.; Ashtami, J.; Mohanan, P. Biomedical application and hidden toxicity of Zinc oxide nanoparticles. Mater. Today Chem. 2018, 10, 175-186. [CrossRef]

15. Iravani, S. Green synthesis of metal nanoparticles using plants. Green Chem. 2011, 13, 2638-2650. [CrossRef]

16. Barabadi, H.; Tajani, B.; Moradi, M.; Kamali, K.D.; Meena, R.; Honary, S.; Mahjoub, M.A.; Saravanan, M. Penicillium Family as Emerging Nanofactory for Biosynthesis of Green Nanomaterials: A Journey into the World of Microorganisms. J. Clust. Sci. 2019, 30, 843-856. [CrossRef]

17. Ahmed, S.; Chaudhry, S.A.; Ikram, S. A review on biogenic synthesis of ZnO nanoparticles using plant extracts and microbes: A prospect towards green chemistry. J. Photoch. Photobiol B. 2017, 166, 272-284. [CrossRef] [PubMed]

18. Garrosa, M.; Jiménez, P.; Tejero, J.; Cabrero, P.; Cordoba-Diaz, D.; Quinto, E.J.; Gayoso, M.J.; Girbés, T. Toxicity of the anti-ribosomal lectin ebulin $\mathrm{f}$ in lungs and intestines in elderly mice. Toxins 2015, 7, 367-379. [CrossRef]

19. Sujitha, M.V.; Kannan, S. Green synthesis of gold nanoparticles using citrus fruits (Citrus limon, Citrus reticulata and Citrus sinensis) aqueous extract and its characterization. Spectrochim. Acta A Mol. Biomol. Spectrosc. 2013, 102, 15-23. [CrossRef]

20. Kaviya, S.; Santhanalakshmi, J.; Viswanathan, B.; Muthumary, J.; Srinivasan, K. Biosynthesis of silver nanoparticles using Citrus sinensis peel extract and its antibacterial activity. Spectrochim. Acta A Mol. Biomol. Spectrosc. 2011, 79, 594-598. [CrossRef]

21. Amanulla, A.M.; Sundaram, R. Green synthesis of $\mathrm{TiO}_{2}$ nanoparticles using orange peel extract for antibacterial, cytotoxicity and humidity sensor applications. Mater. Today Proc. 2019, 8, 323-331. [CrossRef]

22. Patil, B.N.; Taranath, T.C. Limonia acidissima L. leaf mediated synthesis of zinc oxide nanoparticles: A potent tool against Mycobacterium tuberculosis. Int. J. Mycobacteriol. 2016, 5, 197-204. [CrossRef] [PubMed]

23. Kumar, H.K.N.; Mohana, N.C.; Nuthan, B.R.; Ramesha, K.P.; Rakshith, D.R.; Geetha, N.; Satich, S. Phyto-mediated synthesis of zinc oxide nanoparticles using aqueous plant extract of Ocimum americanum and evaluation of its bioactivity. SN Appl. Sci. 2019, 1, 651. [CrossRef]

24. Raja, A.; AshokKumar, S.; Marthandam, R.P.; Jayachandiran, J.; Khatiwada, C.P.; Kaviyarasu, K.; Raman, R.G.; Swaminathan, M.; Kathiwada, C.P. Eco-friendly preparation of zinc oxide nanoparticles using Tabernaemontana divaricata and its photocatalytic and antimicrobial activity. J. Photochem. Photobiol. B Biol. 2018, 181, 53-58. [CrossRef] [PubMed]

25. Pavithra, N.; Lingaraju, K.; Raghu, G.; Nagaraju, G. Citrus maxima (pomelo) juice mediated eco-friendly synthesis of $\mathrm{ZnO}$ nanoparticles: Applications to photocatalytic, electrochemical sensor and antibacterial activities. Spectrochim. Acta A 2017, 185, 11-19. [CrossRef]

26. Steffy, K.; Shanthi, G.; Maroky, A.; Selvakumar, S. Enhanced antibacterial effects of green synthesized ZnO NPs using Aristolochia indica against multidrug resistant bacterial pathogens from diabetic foot ulcer. J. Infect. Public Health. 2018, 11, 463-471. [CrossRef]

27. Attar, A.; Yapaöz, M.A. Biomimetic synthesis, characterization and antibacterial efficacy of $\mathrm{ZnO}$ and $\mathrm{Au}$ nanoparticles using echinacea flower extract precursor. Mater. Res. Express. 2018, 5, 055403. [CrossRef] 
28. Mohammadi-Aloucheh, R.; Habibi-Yangjeh, A.; Bayrami, A.; Latifi-Navid, S.; Asadi, A. Green synthesis of $\mathrm{ZnO}$ and $\mathrm{ZnO} / \mathrm{CuO}$ nanocomposites in Mentha longifolia leaf extract: Characterization and their application as antibacterial agents. J. Mater. Sci. Mater. Electron. 2018, 29, 13596-13605. [CrossRef]

29. Karaköse, E.; Çolak, H. Structural, electrical, and antimicrobial characterization of green synthesized ZnO nanorods from aqueous Mentha extract. MRS Commun. 2018, 8, 577-585. [CrossRef]

30. Padalia, H.; Baluja, S.; Chanda, S. Effect of pH on size and antibacterial activity of Salvadora oleoides leaf extract-mediated synthesis of zinc oxide nanoparticles. BioNanoScience 2017, 7, 40-49. [CrossRef]

31. Supraja, N.; Prasad, T.N.K.V.; Krishna, T.G.; David, E. Synthesis, characterization, and evaluation of the antimicrobial efficacy of Boswellia ovalifoliolata stem bark-extract-mediated zinc oxide nanoparticles. Appl. Nanosci. 2016, 6, 581-590. [CrossRef]

32. Zare, E.; Pourseyedi, S.; Khatami, M.; Darezereshki, E. Simple biosynthesis of zinc oxide nanoparticles using nature's source, and it's in vitro bioactivity. J. Mol. Struct. 2017, 1146, 96-103. [CrossRef]

33. Bala, N.; Saha, S.; Chakraborty, M.; Maiti, M.; Das, S.; Basu, R.; Nandy, P. Green synthesis of zinc oxide nanoparticles using Hibiscus subdariffa leaf extract: Effect of temperature on synthesis, anti-bacterial activity and antidiabetic activity. RSC Adv. 2015, 5, 4993-5003. [CrossRef]

34. Paul, B.; Vadivel, S.; Dhar, S.S.; Debbarma, S.; Kumaravel, M. One-pot green synthesis of zinc oxide nano rice and its application as sonocatalyst for degradation of organic dye and synthesis of 2-benzimidazolederivatives. J. Phys. Chem. Solids 2017, 104, 152-159. [CrossRef]

35. Shokrzadeh, M.; Saravi, S.S.S. The chemistry, pharmacology and clinical properties of Sambucus ebulus: A review. J. Med. Plants Res. 2010, 4, 95-103.

36. Alamdari, S.; Ghamsari, M.S.; Tafreshi, M.J. Optimization of Gallium concentration to improve the performance of $\mathrm{ZnO}$ nanopowders for nanophotonic applications. Ceram. Int. 2020, 46, 4484-4492. [CrossRef]

37. Alamdari, S.; Karkhaneh, A.; Tafreshi, M.J.; Ghamsari, M.S. Ultra-thin Hafnium doped ZnO films with enhaVnced optical transparency and electrical conductivity. Mater. Res. Express 2019, 6, 055020. [CrossRef]

38. Ghamsari, M.S.; Alamdari, S.; Razzaghi, D.; Pirlar, M.A. ZnO nanocrystals with narrow-band blue emission. J. Lumin. 2019, 205, 508-518. [CrossRef]

39. Alamdari, S.; Tafreshi, M.; Ghamsari, M.S. Strong yellow-orange emission from aluminum and Indium co-doped $\mathrm{ZnO}$ nanostructures with potential for increasing the color gamut of displays. Appl. Phys. A. 2019, 125, 165. [CrossRef]

40. Alamdari, S.; Tafreshi, M.J.; Ghamsari, M.S. The effects of indium precursors on the structural, optical and electrical properties of nanostructured thin ZnO films. Mater. Lett. 2017, 197, 94-97. [CrossRef]

41. Ghamsari, M.S.; Alamdari, S.; Han, W.; Park, H.-H. Park, Impact of nanostructured thin ZnO film in ultraviolet protection. Int. J. Nanomed. 2017, 12, 207-216. [CrossRef]

42. Alamdari, S.; Ghamsari, M.S.; Ara, M.M.; Efafi, B. Highly concentrated IZO colloidal nanocrystals with blue/orange/ red three-color emission. Mater. Lett. 2015, 158, 202-204. [CrossRef]

43. Alamdari, S.; Sasani Ghamsari, M.; Jafar Tafreshi, M. Synthesis, characterization and gas sensing properties of In-doped ZnO nanopowders. Nanochem. Res. 2017, 2, 198-204.

44. Vafaee, M.; Ghamsari, M.S.; Radiman, S. Highly concentrated zinc oxide nanocrystals sol with strong blue emission. J. Lumin. 2011, 131, 155-158. [CrossRef]

45. Bauer, A.W.; Kirby, W.M.M.; Sherris, J.C.; Turck, M. Antibiotic susceptibility testing by a standardized single disk method. Am. J. Clin. Pathol. 1966, 45, 493-496. [CrossRef]

46. Pick, E.; Mizel, D. Rapid microassays for the measurement of superoxide and hydrogen peroxide production by macrophages in culture using an automatic enzyme immunoassay reader. J. Immunol. Methods 1981, 46, 211-226. [CrossRef]

47. Cope, J.O.; Campbell, I.D. Electron spin resonance observations of oxygen chemisorption on zinc oxide. J. Chem. Soc. Faraday Trans. 1973, 1, 1-9. [CrossRef]

48. Kaftelen, H.; Ocakoglu, K.; Thomann, R.; Tu, S.; Weber, S.; Erdem, E. EPR and photoluminescence spectroscopy studies on the defect structure of ZnO nanocrystals. Phys. Rev. B 2012, 86, 014113. [CrossRef]

49. Efafi, B.; Ghamsari, M.S.; Aberoumand, M.A.; Ara, M.M.; Ghamsari, A.H.S.; Rad, H.H. Aluminum doped ZnO sol-gel derived nanocrystals: Raman spectroscopy and solid solubility characterization. Phys. Status Solidi A 2014, 211, 2426-2430. [CrossRef] 
50. Sundrarajan, M.; Ambika, S.; Bharathi, K. Plant-extract mediated synthesis of ZnO nanoparticles using Pongamia pinnata and their activity against pathogenic bacteria. Adv. Powder Technol. 2015, 26, 1294-1299. [CrossRef]

51. Senthilkumar, N.; Nandhakumar, E.; Priya, P.; Soni, D.; Vimalan, M.; Potheher, I.V. Synthesis of ZnO nanoparticles using leaf extract of Tectona grandis (L.) and their anti-bacterial, anti-arthritic, anti-oxidant and in vitro cytotoxicity activities. New J. Chem. 2017, 41, 10347-10356. [CrossRef]

52. Stan, M.; Popa, A.; Toloman, D.; Silipas, T.-D.; Vodnar, D.C. Antibacterial and antioxidant activities of ZnO nanoparticles synthesized using extracts of Allium sativum, Rosmarinus officinalis and Ocimum basilicum. Acta Met. Sin. Engl. Lett. 2016, 29, 228-236. [CrossRef]

53. Romero, R.; López-Ibáñez, R.; Dalchiele, E.A.; Ramos-Barrado, J.R.; Martín, F.; Leinen, D. Compositional and physico-optical characterization of $0-5 \%$ Al-doped zinc oxide films prepared by chemical spray pyrolysis. J. Phys. D Appl. Phys. 2010, 43, 095303. [CrossRef]

54. Al-Gaashani, R.; Radiman, S.; Daud, A.; Tabet, N.; Al-Douri, Y. XPS and optical studies of different morphologies of $\mathrm{ZnO}$ nanostructures prepared by microwave methods. Ceram. Int. 2013, 39, 2283-2292. [CrossRef]

55. Dayioglu, H.; Kut, D.; Merdan, N.; Eyupoglu, S. The effect of dyeing properties of fixing agent and plasma treatment on silk fabric dyed with natural dye extract obtained from Sambucus ebulus L. plant. Procedia Soc. Behav. Sci. 2015, 195, 1609-1617. [CrossRef]

56. Vafaee, M.; Ghamsari, M.S. Preparation and characterization of ZnO nanoparticles by a novel sol-gel route. Mater. Lett. 2007, 61, 3265-3268. [CrossRef]

57. Wetchakun, N.; Chaiwichain, S.; Inceesungvorn, B.; Pingmuang, K.; Phanichphant, S.; Minett, A.I.; Chen, J. $\mathrm{BiVO}_{4} / \mathrm{CeO}_{2}$ nanocomposites with high visible-light-induced photocatalytic activity. ACS Appl. Mater. Interfaces 2012, 4, 3718-3723. [CrossRef]

58. Liang, H.; Tai, X.; Du, Z.; Yin, Y. Enhanced photocatalytic activity of ZnO sensitized by carbon quantum dots and application in phenol wastewater. Opt. Mater. 2020, 100, 109674. [CrossRef]

59. Ngoepe, N.; Mbita, Z.; Mathipa, M.; Mketo, N.; Ntsendwana, B.; Hintsho-Mbita, N. Biogenic synthesis of ZnO nanoparticles using Monsonia burkeana for use in photocatalytic, antibacterial and anticancer applications. Ceram. Int. 2018, 44, 16999-17000. [CrossRef]

60. Meena, S.; Vaya, D.; Das, B.K. Photocatalytic degradation of Malachite Green dye by modified ZnO nanomaterial. Bull. Mater. Sci. 2016, 39, 1735-1743. [CrossRef]

61. Nava, O.; Morales, P.L.; Gutiérrez, C.M.G.; Vilchis-Nestor, A.; Castro-Beltrán, A.; Mota-González, M.; Olivas, A. Influence of Camellia sinensis extract on zinc oxide nanoparticle green synthesis. J. Mol. Struct. 2017, 1134, 121-125. [CrossRef]

62. Ambika, S.; Sundrarajan, M. Antibacterial behaviour of Vitex negundo extract assisted ZnO nanoparticles against pathogenic bacteria. J. Photochem. Photobiol. B Biol. 2015, 146, 52-57. [CrossRef] [PubMed]

63. Sinha, R.; Karan, R.; Sinha, A.; Khare, S.K. Interaction and nanotoxic effect of ZnO and Ag nanoparticles on mesophilic and halophilic bacterial cells. Bioresour. Technol. 2011, 102, 1516-1520. [CrossRef] [PubMed]

64. Jones, N.; Ray, B.; Ranjit, K.T.; Manna, A.C. Antibacterial activity of ZnO nanoparticle suspensions on a broad spectrum of microorganisms. FEMS Microbiol. Lett. 2008, 297, 71-76. [CrossRef] [PubMed]

65. Jayaseelan, C.; Rahuman, A.A.; Kirthi, A.V.; Marimuthu, S.; Santhoshkumar, T.; Bagavan, A.; Gaurav, K.; Karthik, L.; Rao, K.V.B. Novel microbial route to synthesize ZnO nanoparticles using Aeromonas hydrophila and their activity against pathogenic bacteria and fungi. Spectrochim. Acta A 2012, 90, 78-84. [CrossRef]

66. Singh, V.; Mishra, A.K. White light emission from vegetable extracts. Sci. Rep. 2015, 5, 11118. [CrossRef]

67. Padmavath, N.; Vijayaraghavan, R. Enhanced bioactivity of ZnO nanoparticles-an antimicrobial study. Sci. Technol. Adv. Mater. 2008, 9, 035004. [CrossRef]

68. Fernández, L.; Hancock, R.E.W. Adaptive and mutational resistance: Role of porins and efflux pumps in drug resistance. Clin. Microbiol. Rev. 2012, 25, 661. [CrossRef]

69. Yamamoto, O.; Komatsu, M.; Sawai, J.; Nakagawa, Z. Antibacterial activity of ZnO particle with crystallographic orientation. J. Mater. Sci. Mater. Med. 2008, 19, 1407-1412.

70. Luo, F.; Yang, D.; Chen, Z.; Megharaj, M.; Naidu, R. One-step green synthesis of bimetallic Fe/Pd nanoparticles used to degrade Orange II. J. Hazard. Mater. 2016, 3030, 145-153. [CrossRef]

71. Mittal, A.K.; Chisti, Y.; Banerjee, U.C. Synthesis of metallic nanoparticles using plant extracts. Biotechnol. Adv. 2013, 31, 346-356. [CrossRef] 
72. Weng, X.; Guo, M.; Luo, F.; Chen, Z. One-step green synthesis of bimetallic Fe/Ni nanoparticles by eucalyptus leaf extract: Biomolecules identification, characterization and catalytic activity. Chem. Eng. J. 2017, 308, 904-911. [CrossRef]

73. Wu, J.M.; Kao, W.T. Heterojunction nanowires of $\mathrm{Ag}_{\mathrm{x}} \mathrm{Zn}_{1-\mathrm{x}} \mathrm{O}-\mathrm{ZnO}$ photocatalytic and antibacterial activities under visible-light and dark conditions. J. Phys. Chem. C. 2015, 119, 1433-1441. [CrossRef]

74. Umar, H.; Kavaz, D.; Rizaner, N. Biosynthesis of zinc oxide nanoparticles using Albizia lebbeck stem bark, and evaluation of its antimicrobial, antioxidant, and cytotoxic activities on human breast cancer cell lines. Int. J. Nanomed. 2019, 14, 87-100. [CrossRef] [PubMed]

75. Kumar, N.H.; Murali, M.; Satish, A.; Singh, S.B.; Gowtham, H.G.; Mahesh, H.M.; Lakshmeesha, T.R.; Amruthesh, K.N.; Jagannath, S. Bioactive and Biocompatible Nature of Green Synthesized Zinc Oxide Nanoparticles from Simarouba glauca DC.: An Endemic Plant to Western Ghats, India. J. Clust. Sci. 2020, 31, 523-534. [CrossRef]

76. Arvanag, F.M.; Bayrami, A.; Habibi-Yangjeh, A.; Pouran, S.R.; Mohammadi, F. Pouran, A comprehensive study on antidiabetic and antibacterial activities of $\mathrm{ZnO}$ nanoparticles biosynthesized using Silybum marianum $\mathrm{L}$. seed extract. Mater. Sci. Eng. C 2019, 97, 397-405. [CrossRef]

77. Parashant, G.K.; Prashant, P.A.; Utpal, B.; Manoj, G.; Nagabhushana, B.M.; Ananda, S.; Krishnaiah, G.M.; Sathyananda, H.M. In vitro antibacterial and cytotoxicity studies of $\mathrm{ZnO}$ nanoparticles prepared by combustion assisted facile green synthesis. Karbala Int. J. Mod. Sci. 2015, 1, 67-77.

78. Rogers, N.J.; Apte, S.C.; Batley, G.E.; Gadd, G.E.; Casey, P.S. Comparative toxicity of nanoparticulate $\mathrm{ZnO}$, bulk $\mathrm{ZnO}$, and $\mathrm{ZnCl} 2$ to a freshwater microalga subcapitata: The importance of particle solubility. Environ. Sci. Technol. 2007, 41, 8484-8490.

79. Agarwal, H.; Menon, S.; Kumar, S.V.; Rajeshkumar, S. Mechanistic study on antibacterial action of zinc oxide nanoparticles synthesized using green route. Chemico-Biol. Interact. 2018, 286, 60-70. [CrossRef]

80. Arakha, M.; Saleem, M.; Mallick, B.C.; Jha, S. The effects of interfacial potential on antimicrobial propensity of $\mathrm{ZnO}$ nanoparticle. Sci. Rep. 2015, 5, 9578. [CrossRef]

81. Leung, Y.H.; Chan, C.M.N.; Ng, A.M.C.; Chan, H.T.; Chiang, M.W.L. Antibacterial activity of ZnO nanoparticles with a modified surface under ambient illumination. Nanotechnology 2012, 23, 475703. [CrossRef]

82. Peng, X.; Palma, S.; Fisher, N.S.; Wong, S.S. Effect of morphology of ZnO nanostructures on their toxicity to marine algae. Aquat. Toxicol. 2011, 102, 186-196. [CrossRef] [PubMed]

83. Sangeetha, G.; Rajeswari, S.; Venkatesh, R. Green synthesized ZnO nanoparticles against bacterial and fungal pathogens. Prog. Nat. Sci. Mater. Int. 2012, 22, 693-700.

84. Susheela, S.; Sunil, K.; Bulchandini, B.D.; Shalini, T.; Shelza, B. Green synthesized ZnO nanoparticles against bacterial and fungal pathogens. Int. J. Biotechnol. Bioeng. Res. 2013, 4, 341-346. 